\title{
Homenagem a Charles Tilly (1929-2008)
}

Por Angela M. Alonso

Na primeira vez em que bati à sua porta, em 1998, eu tinha uma vaga idéia de quem ele era. Logo surgiram, de sua vasta sala na Universidade de Columbia, uns olhos de um azul muito vívido emoldurados por cabelos brancos em cacho. "Professor Tilly?", eu perguntei intimidada. Não trazia carta de apresentação nem outra credencial que a de estudante brasileira. "Me chame de Chuck", ele respondeu, abrindo seu largo e cativante sorriso. Nas suas aulas, nas quais fui prontamente aceita, soube logo que a informalidade era a ponta mais visível de seu igualitarismo. Alunos de todas as partes do mundo, ignorantes nos assuntos que ele dominava, eram convidados a palpitar sobre seus livros em andamento. Ali estava, logo percebi, um cérebro privilegiado, que dava concretude à noção sempre intangível de gênio, com sua assombrosa erudição e o controle de todos os debates da sociologia, da história e da ciência política. Tudo transmitido em falas coloquiais, curtas, precisas e brilhantes, no duplo sentido de esclarecedoras e luminares.

O mesmo se via nas sessões do seminário que ele criou na Universidade de Michigan (quando era chamado de "Think, then drink"), levou consigo para a New School of Social Research e de lá para a Columbia. Em seus mais de trinta anos de funcionamento, o "Contentious Politics" misturou, sob a batuta do maestro (que amava o jazz e a música clássica), de doutorandos a figurōes consagrados, escrevendo sobre três ou quatro séculos e todas as regiōes do globo em torno de um dos muitos assuntos em que Tilly 
pontificou: desigualdade, formação do Estado nacional, urbanização, movimentos sociais, explicação sociológica.

Pelo seu seminário passaram centenas de papers, inclusive muitos dos cerca de 600 artigos e 51 livros que Tilly publicou. Alguns já nasceram clássicos, como The Vendée: a sociological analysis of the counter-revolution of 1793(1964); From mobilization to revolution (1978); As sociology meets history (1981); Bigstructures, large processes, huge comparisons (1984); The contentious french (1983); European revolutions 1492-1992 (1993); Cities and the rise of States in Europe: A.D. 1000 to 1800 (1994); Durable inequality (1998); Dynamics of contention (2001); Social movements 1768-2004 (2004); Trust and rule (2005); Why? (2006). Títulos seus foram traduzidos para várias línguas (em português há apenas Coerção, capital e Estados europeus, 9001900) e lhe valeram prêmios e honrarias acadêmicas, como o American Sociological Association's Career of Distinguished Scholarship Award, em 2005, e convites para ensinar em prestigiosas universidades mundo afora.

Em seus trabalhos, Tilly combinou, com rigor e elegância, teorização e pesquisa empírica, análise histórica e conjuntural, dados qualitativos e quantitativos. Tomando a Europa dos últimos quatro séculos como seu referente empírico principal, Tilly primava por uma abordagem macrohistórica, o que the valeu críticas reiteradas de excessivo estruturalismo. Em resposta a elas, vinha construindo uma abordagem mais permeável à agência e às dimensôes culturais da vida social. É o que se lê em Identities, boundaries and social ties (2006) e é o que promete ser o cerne de seu ainda inédito Credit and blame. Essa inflexão em sua obra é só um exemplo de seu antidogmatismo, sempre pronto a acolher críticas e aprender com elas.

Tilly ainda achava tempo para regularmente aconselhar desenhos de pesquisa, ler e comentar livros, discutir teses e papers de quem o requisitasse. Jamais deixava alguém sem resposta. Era sempre amável e prestativo, como foi com a Tempo Social, concedendo uma entrevista, aceitando compor seu Conselho Editorial e enviando artigos, quando estava já debilitado pelo câncer.

Generosidade atestada pela avalanche de e-mails emocionados que, desde de sua morte, em 29 de abril, vem inundando a lista de discussão que ele mantinha com ex-alunos e colaboradores. Um deles fez certa vez uma resenha em versos de um livro de Tilly. Em meio a várias ressalvas, chamou-o de gigante das ciências sociais. Na resposta em soneto, Tilly ofereceu seus ombros para que o crítico edificasse sobre eles uma nova teoria. A oferta não era retórica. Tilly de fato ajudou Jeff Goodwin e cen- 
tenas de outros, como eu, a escrever seus livros, a partir de suas próprias idéias. O "gigante" de Goodwin tampouco era uma metáfora. A monumentalidade e a qualidade da obra de Tilly o atestam; ela já impactou quatro gerações de sociólogos, o que por si só configura uma forma de imortalidade.

As idéias de Charles Tilly estão vivas e potentes. Mas Chuck vai fazer muita falta para aqueles que tiveram a honra e o prazer de conhecê-lo. 